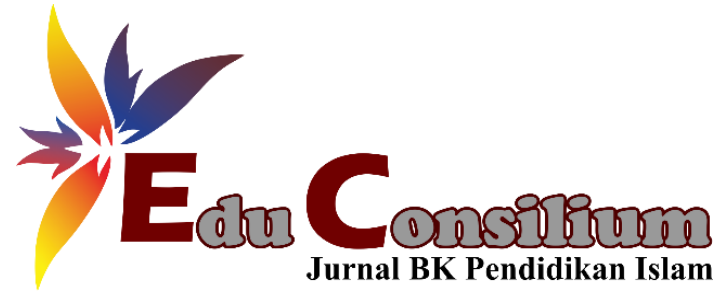

\title{
DENIAL SYNDROME TERHADAP PANDEMI COVID-19 PADA MASYARAKAT KABUPATEN PAMEKASAN MADURA
}

\footnotetext{
${ }^{1}$ Iswatun Hasanah, ${ }^{2}$ Imaniyatul Fithriyah, ${ }^{3}$ Septinda Rima Dewanti, ${ }^{4}$ Sri Rizqi Wahyuningrum

${ }^{1}$ Bimbingan dan Konseling Pendidikan Islam, Institut Agama Islam Negeri Madura, Jalan Panglegur KM 04, Pamekasan, Timur, 69371, Indonesia

${ }^{2}$ Bimbingan dan Konseling Pendidikan Islam, Fakultas Tarbiyah, IAI Al-Khairat Pamekasan, jalan raya Palengaan (palduding) No.2, Pamekasan, Timur, 69362, Indonesia

${ }^{3}$ Bimbingan dan Konseling, Fakultas Ilmu Pendidikan, Universitas Negeri Yogyakarta, Jalan Colombo No. 1,

Karang malang, Yogyakarta, 55281, Indonesia

${ }^{4}$ imbingan dan Konseling Pendidikan Islam, Fakultas Tarbiyah, IAIN Madura, Jalan Panglegur KM 04, Pamekasan, Timur, 69301, Indonesia

*Iswatun Hasanah, iswatun_hasanah@iainmadura.ac.id
} 


\begin{tabular}{ll}
\hline \hline & Abstract \\
\hline Keywords: & The Covid-19 pandemic in Pamekasan Regency has had a major impact on various \\
Syndrome & aspects of people's lives, especially in terms of health, which can cause respiratory \\
Keyword 2; Pandemi & system disorders, severe lung infections, and even death. The frightening condition \\
Covid-19 & of the Covid-19 pandemic can lead to denial and denial of the truth (Denial \\
Keyword 3; Kabupaten & $\begin{array}{l}\text { Syndrome). Denial Syndrome is a form of self-defense against anxiety against a } \\
\text { Pamekasan }\end{array}$ \\
& $\begin{array}{l}\text { logreatening reality. In the short term Denial Syndrome will help individuals think } \\
\text { will be dangerous and cause problems for themselves or the environment. Therefore, }\end{array}$ \\
& this study aims to determine the behavior of the community's denial syndrome \\
& against the covid 19 pandemic. Empirical phenomenological research through \\
& observations and interviews regarding the behavior of the Pamekasan community in \\
dealing with the Covid-19 pandemic, this shows Denial Syndrome's attitude towards \\
the Covid-19 pandemic in the form of behavior Not paying attention to health \\
protocols can result in faster transmission of the virus. Therefore, every individual \\
must be able to accept and be aware of the existence of the corona virus and its \\
impact on themselves and others by making various efforts so that they can continue \\
to carry out routines without conflicting with government regulations. This can be a \\
solution for individuals to get out of their comfort zone and make peace with \\
themselves and the situation so that this Pandemic can be resolved properly.
\end{tabular}

\begin{tabular}{ll}
\hline \hline & Abstrak: \\
\hline Kata Kunci: & Pandemi Covid-19 di Kabupaten Pamekasan berdampak besar pada berbagai aspek \\
Kata Kunci 1; Denial & kehidupan masyarakat, terutama dari segi kesehatan yakni dapat menyebabkan \\
Syndrome & gangguan sistem pernapasan, infeksi paru-paru yang berat, hingga kematian. Kondisi \\
Kata Kunci 2; & yang menakutkan akan Pandemi Covid-19 dapat memunculkan perilaku \\
Pandemi Covid-19 & penyangkalan dan menolak akan kebenaran (Denial Syndrome). Denial Syndrome \\
Kata Kunci 3; & merupakan bentuk pertahanan diri dalam melawan kecemasan terhadap kenyataan \\
& yang mengancam. Dalam jangka pendek Denial Syndrome akan membantu individu \\
& berpikir logis dan berdamai dengan ketakutan diri sendiri, tetapi Denial Syndrome \\
& dalam jangka panjang akan membahayakan dan menimbulkan masalah pada diri \\
& sendiri ataupun lingkungan sekitar. Oleh karena itu penelitian ini bertujuan untuk \\
& mengetahui perilaku denial syndrome masyarakat terhadap pandemi covid 19. Riset \\
& fenomenologi empiris melalui observasi dan wawancara mengenai perilaku-perilaku \\
& masyarakat Pamekasan dalam menghadapi pandemi Covid-19, hal ini menunjukkan \\
& sikap Denial Syndrome terhadap pandemi Covid-19 berupa perilaku kurang \\
& memperhatikan protokol kesehatan sehingga berakibat penularan virus yang semakin \\
& cepat. Oleh karena itu setiap individu harus bisa menerima dan menyadari \\
& keberadaan virus corona dan dampaknya bagi diri dan orang lain dengan melakukan \\
& berbagai usaha agar tetap dapat menjalankan rutinitas tanpa bertentangan dengan \\
& aturan pemerintah. Hal ini dapat menjadi solusi bagi individu keluar dari zona \\
& nyaman dan berdamai dengan diri sendiri dan keadaan sehingga Pandemi ini bisa \\
& segera teratasi dengan baik.
\end{tabular}

CEdu Consilium: Jurnal Bimbingan dan Konseling Pendidikan Islam Institut Agama Islam Negeri Madura, Indonesia

\section{PENDAHULUAN}

Pamekasan merupakan salah satu Kabupaten yang berada di kawasan pulau Madura dengan luas $972,30 \mathrm{~km}^{2}$. Secara astronomis terletak pada 6051'-7031' Lintang Selatan dan 113019'- 113058' Bujur Timur dan berada pada ketinggian antara 6-312 meter dari permukaan laut (dpl). Berdasarkan batas-batasnya Kabupaten Pamekasan berada di sebelah Utara Laut Jawa, batas selatan terdapat Selat Madura, sebelah Barat berbatasan dengan Kabupaten Sampang dan sebelah Timur berbatasan dengan Kabupaten Sumenep, serta 
Kabupaten Pamekasan memiliki 13 kecamatan, 178 desa, serta 11 kelurahan (Kabupaten Pamekasan, 2021). Kabupaten Pamekasan juga memiliki ciri khas tersendiri baik dari segi sumber daya alam maupun manusia nya. Pamekasan dikenal dengan sebutan Kota Batik dan Gerbang Salam, hal ini dikarenakan menjamurnya masyarakat yang menekuni usaha batik, baik dalam hal kerajinannya maupun usaha penjualannya. Bahkan sebelum adanya Pandemi, kabupaten Pamekasan sering mengadakan event-event yang menampilkan kerajinan batik, baik dikemas dalam bentuk "karnaval"/ Parade maupun pemilihan duta putri batik.

Pamekasan dinobatkan sebagai salah satu kabupaten berpendidikan mengingat keberhasilan Kabupaten Pamekasan dalam menggalakkan pendidikan, sehingga dari tahun ke tahun terus bertabur prestasi baik dari tingkat lokal, regional, hingga internasional. (Kabupaten Pamekasan, 2021). Selain itu di Pamekasan banyak lembaga pendidikan mulai dari tingkat Paud sampai perguruan tinggi. Dari berbagai lembaga pendidikan banyak siswa/siswi nya yang sudah mengharumkan bangsa Indonesia dalam olimpiade nasional maupun internasional di bidang akademik maupun non akademik. Salah satu sekolah yang sudah sering memberikan kontribusi dalam mendelegasikan siswa-siswanya di tingkat nasional dan internasional yakni SMAN 1 Pamekasan.

Secara karakteristik individu Pamekasan juga ada kemiripan dengan ketiga Kabupaten lainnya, yakni stereotype yang melekat pada masyarakat di Pamekasan tak ubahnya dengan Kabupaten lainnya di pulau Madura, diantaranya perilaku “carok", keras kepala, kaku, tempramental, dan perilaku sulit diatur serta perilaku positif dan negatif lainnya. Salah satu yang menjadi indikasi masyarakat madura khususnya Pamekasan keras kepala yakni salah satu contohnya penjual-penjual di pasar-pasar tradisional yang sulit diatur, apalagi pasar yang menjual hewan ternak (misalnya sapi dan kambing), tak jarang lalu lintas mengalami masalah (macet) karena penjual banyak memarkir kendaraan tidak pada tempatnya, berjualan di pinggir jalan, bahkan banyak yang sampai melewati bahu jalan. Diantara pasar yang dikenal yakni pasar "Keppo" dan pasar 17 Agustus (phasar bhara'). Tidak jarang petugas terlihat kewalahan dalam mengatur lalu lintas untuk mencegah kemacetan. Hal yang tidak jauh berbeda dipasar lainnya, misalnya pasar Blumbungan, pasar Waru, Pasar pakong, yang sampai berjualan di bahu jalan dengan asumsi agar jualan mereka cepat laku tanpa menghiraukan kelancaran lalu lintas di sekitarnya. Kondisi seperti ini, juga masih nampak walaupun sedang dalam kondisi pandemi. Masyarakat tampak enggan mematuhi aturan pemerintah untuk selalu mematuhi protokol kesehatan dimanapun berada. 
Berdasarkan data statistik per tanggal 26 juli 2021 masyarakat yang didiagnosis positif covid berdasarkan hasil tes (PCR/ Rapid Tes) sebanyak 3,19 juta kasus, sembuh 2,55 juta kasus, dan meninggal 84.766 kasus (CSSEGISandData/Covid-19, 2021). Adapun Provinsi dengan jumlah kematian tertinggi per tanggal 25 Juli 2021 yaitu provinsi jawa Timur dengan kasus yang terkonfirmasi positif mencapai 272.337 orang dan yang meninggal mencapai 17.858 orang (Rizal, 2021). Periode bulan Juni 2021 loncakan tajam kasus covid19 terbaru yakni varian Delta terjadi pulau Madura, terutama di Kabupaten bangkalan dan ketiga kabupaten lainnya. Bahkan menurut pakar kesehatan peningkatan kasus di pulau Madura bisa jauh lebih besar dari kasus yang tercatat (Mustopa, 2021).

Virus Corona atau severe acute respiratory syndrome coronavirus 2 (SARS-CoV2) adalah virus yang dapat menyerang sistem pernapasan manusia baik pada anak-anak, remaja, dewasa, ataupun orang tua. Penyakit karena infeksi virus ini disebut COVID-19. Virus Corona bisa menyebabkan gangguan ringan, sedang dan berat pada sistem pernapasan, infeksi paru-paru yang berat, hingga kematian. Pandemi mulai mewabah di Indonesia diawal Maret 2020 dan berangsur-angsur menjadi kondisi yang memprihatinkan yang berdampak besar dalam berbagai aspek kehidupan masyarakat, diantaranya pada bidang kesehatan, ekonomi, pendidikan, pariwisata, serta bidang yang lainnya.

Pemerintah melakukan berbagai cara untuk menanggulangi pandemi covid-19 di berbagai daerah, mulai dari PSBB (Pembatasan Sosial Berskala Besar), pemberian bantuan berupa uang tunai maupun kebutuhan pokok untuk masyarakat terdampak, pemberian vaksin secara bertahap kepada masyarakat, dan PPKM (Pemberlakuan Pembatasan Kegiatan Masyarakat). PPKM tidak hanya diberlakukan di kota-kota besar, bahkan di kabupaten Pamekasan-pun juga melaksanakan PPKM. Pamekasan juga menerapkan setiap warga dari luar yang ingin ke Pamekasan ataupun warga yang ingin keluar Pamekasan harus memiliki Surat Izin keluar Masuk (SIKM) dalam rangka mencegah meluasnya Covid-19 (Aziz, 2021). PPKM di Pamekasan dilaksanakan dengan memperketat protokol kesehatan di area tertentu, serta penyekatan-penyekatan untuk meminimalisir mobilitas warga, Lampu jalan banyak yang dimatikan waktu malam hari, toko-toko, rumah makan dan kafe di area kota harus tutup jam 20.00. Tetapi hal ini berlaku di area kota, untuk masyarakat yang tinggal di pinggiran atau desa, toko dan warung masih tetap buka seperti biasa dimalam hari serta aktivitas warga masih terlihat normal seperti tidak ada aturan PPKM.

PPKM digalakkan oleh pemerintah daerah di Pamekasan bukan tanpa sebab. Meluasnya Covid-19 yang begitu cepat mengakibatkan pemerintah daerah kelimpungan. 
Rumah Sakit Umum Daerah Kabupaten Pamekasan (RSUD Dr. H. Slamet Martodirdjo) tidak bisa menampung banyaknya jumlah pasien yang membutuhkan perawatan sehingga di bangunnya tenda darurat di depan rumah sakit Kabupaten Pamekasan sebagai tempat isolasi dalam merawat pasien Covid-19 . Menurut Syaiful Hidayat selaku Ketua tim penanganan pasien Covid-19 menyampaikan bahwa tenda darurat yang dibangun di RSUD Pamekasan karena imbas lonjakan Covid-19 tidak cukup untuk menampung pasien meskipun di RSUD sudah terdapat lima ruang isolasi ditambah satu ruang instalasi gawat darurat/ IGD (Fea, 2021).

Adapun keluhan dari pasien hampir memiliki kesamaan yakni panas, menggigil, lemas, badan terasa sakit, serta sesak nafas. Menurut kesaksian seorang keluarga pasien, untuk memperoleh pemeriksaan awal di IGD pasien harus antri terlebih dahulu di lorong rumah sakit, bahkan tidak jarang ditemui pasien meninggal sebelum mendapatkan pemeriksaan karena banyaknya warga yang sakit. Hal senada juga disampaikan oleh dr. Syaiful yakni rumah sakit tidak bisa menampung banyaknya pasien yang datang dan daftar antrian yang dalam sehari bisa mencapai dua belas sampai delapan belas pasien (Fea, 2021). Rumah sakit rujukan di Pamekasan ruang isolasi juga penuh, baik kamar maupun ruang isolasinya. Sehingga banyak warga yang sakit juga memilih mendapatkan perawatan di rumah sendiri, minum obat dari hasil informasi yang diperoleh dari media internet atau media sosial, bahkan meminta bantuan pada mantri/ perawat yang bersedia untuk memberikan penanganan.

Obat-obatan di apotek-pun juga banyak yang langka, banyaknya warga yang sakit dan panik membuat ketersediaan obat di apotek menipis dan bahkan habis, terutama vitamin $\mathrm{C}$ dan obat-obatan yang biasanya digunakan untuk penanganan pasien covid-19. Dari hasil informasi seorang pembeli sebut saja Putri, yang sedang mencari vermint (sari cacing) dan neorobion di berbagai apotik di kota Pamekasan tidak tersedia, bahkan di apotek K-24 yang terletak di area kota memberikan papan informasi jenis obat-obatan yang tidak tersedia karena banyaknya warga yang bertanya tentang obat-obatan yang habis. Berdasarkan hasil observasi, dalam bulan Juni dan Juli 2021 seringkali terlihat keramaian di apotek dengan pembelian obat-obatan yang hampir sama, misalnya vitamin C, obat paracetamol, neurobion, antibiotik, dan obat lainnya.

Data di rumah sakit mengenai pasien yang terkonfirmasi covid-19 tidak mencakup data warga yang sakit mendapatkan penanganan di rumah masing-masing. Menurut informasi salah satu warga, di beberapa desa banyak orang meninggal dengan gejala yang sama, yakni 
sesak nafas, panas, lemas, menggigil, dan ciri-ciri lain yang mengarah pada covid-19. Tak jarang di desa-desa berita kematian dalam satu hari bisa mencapai 2 sampai 3 orang. Bahkan banyak warga yang sakit dan diikuti oleh anggota keluarga yang lain, dan sudah menjadi hal yang umum jika setiap keluarga yang sakit menunjukkan gejala covid-19. Covid-19 oleh warga di desa-desa dan pinggiran kota Pamekasan disebut dengan istilah berbeda. Masyarakat di Pamekasan khususnya di area pinggiran dan desa-desa, jika berkunjung menjeguk orang yang sakit ataupun ngelayat orang yang meninggal karena positif covid-19 menyebutnya dengan "Penyaket satiyaan" (dalam bahasa madura) artinya penyakit terkini (covid-19).

Jumlah pasien covid 19 di rumah sakit umum daerah dan rumah sakit rujukan semakin membludak, ramainya warga membeli obat-obatan di apotek, banyaknya warga yang sakit dengan gejala covid-19, serta berita kematian yang tidak seperti biasanya di berbagai desa, dapat menjadi ciri bahwa hal ini disebabkan karena penularan covid-19 di Kota Pamekasan yang tidak terkendali. Tetapi hal ini bertolak belakang dengan kondisi yakni di desa-desa menjenguk orang sakit, melayat, bahkan di pasar-pasar tradisional masih tetap melakukan aktifitas seperti biasanya tanpa menggunakan masker, tanpa menjaga jarak, dan protokol kesehatan lainnya. Keramaian masih sangat terlihat di pasar 17 Agustus, Kolpajung, Blumbungan, pasar Keppo, pasar Ghurem, dan pasar tradisional lainnya walaupun dalam kondisi PPKM. Perilaku masyarakat yang menunjukkan seolah-olah tutup mata/ tidak peduli terhadap kesehatan dan penularan covid-19 bahkan banyak masyarakat yang menyebutnya bukan corona/ covid-19 tetapi dengan menggunakan istilah "penyaket satiyaan" menjadi semacam mekanisme pertahanan diri untuk menurunkan ketakutan dan kekhawatiran terhadap dampak serius yang disebabkan karena pandemi Covid-19, dan Kondisi tersebut bisa dikategorikan dalam Denial Syndrome.

Denial Syndrome merupakan salah satu jenis mekanisme pertahanan diri yang dikemukakan oleh Sigmund Freud seorang ahli Psikologi dari Austria dengan teorinya yang terkenal adalah Psikoanalisis. Mekanisme pertahanan diri merupakan strategi psikologis yang dilakukan individu dalam mempertahankan citra diri dan menyamankan diri sendiri (semacam pertahanan diri secara psikologis). Denial Syndrome merupakan bentuk pertahanan diri dalam melawan kecemasan terhadap kenyataan yang mengancam. (Corey, 2005). Individu menolak kenyataan yang membangkitkan kecemasan dan ketakutan. Ketakutan akan sakit, keluarga yang meninggal, ataupun kematian diri sendiri. Pada pandemi covid-19 sering 
dimanifestasikan penyangkalan (Denial Syndrome) terhadap fakta dampak dari covid-19 baik terhadap keluarga besar ataupun diri sendiri.

Dalam kasus penyangkalan, individu bisa saja memilih untuk tidak mengakui kenyataan atau menyangkal konsekuensi dari kenyataan tersebut. Misalnya tidak peduli dengan peraturan pemerintah pusat dan daerah untuk membatasi kegiatan di luar rumah, tidak menggunakan protokol kesehatan seperti yang dianjurkan oleh pemerintah daerah maupun pusat, tetap menyelenggarakan hajatan pernikahan layaknya hari biasa, bahkan tidak terima jika orang terdekat yang sakit atau meninggal karena terpapar virus Covid-19, ataupun banyak yang mengkaitkannya dengan hal mistis yakni melarang menjawab salam/ jika ada yang memanggil di malam hari (mendengar suara orang memanggil), karena dianggap dapat membuat orang yang menjawab sakit ataupun meninggal. Syaiful Hidayat menyampaikan terdapat kasus warga tolak protokol kesehatan misalnya terjadi di Waru, yakni keluarga korban dan warga mengambil paksa jenazah yang positif covid-19, dikarenakan akan dikuburkan sendiri jenazah tersebut tanpa protokol covid, bahkan karena kejadian tersebut petugas juga terluka dan ambulans pun mengalami kerusakan karena warga yang menghadang cukup banyak. Kejadian lain misalnya di Tlanakan yang akan membakar puskesmas karena ada pasien dinyatakan positif covid-19 (Dea, 2020). Berdasarkan fakta yang telah diuraikan tersebut diketahui tujuan dalam penelitian ini yaitu untuk mengetahui perilaku denial syndrome masyarakat terhadap pandemi covid 19.

\section{METODE PENELITIAN}

Sebagaimana permasalahan yang sudah dipaparkan diatas maka peneliti memilih menggunakan tipe riset fenomenologi empiris, hal ini dikarenakan fenomenologi mengamati suatu fenomena atau gejala alamiah yang tampak. Jadi peneliti berusaha memahami fenomena-fenomena yang terjadi pada subyek yang akan diteliti, sehingga yang ditekankan adalah aspek subjektivitas subyek. Peneliti berusaha memasuki "dunia" subyek dalam memahami apa dan bagaimana makna yang dikembangkan subyek dalam kehidupan seharihari. Riset fenomenologi bertujuan untuk menginterpretasikan tindakan sosial individu dengan individu yang lain sebagai sesuatu yang bermakna (memiliki makna)

Peneliti melakukan pengumpulan data dengan menggunakan interview mendalam dan observasi karena peneliti ingin mengamati dengan lebih mendalam bentuk denial syndrome yang terjadi pada masyarakat selama ini sehingga bisa didapatkan data yang lebih menyeluruh dan valid. Peneliti sebagai instrumen sekaligus pengumpul data, yang ikut 
berpartisipasi aktif dari kelompok yang diamatinya. Peneliti melakukan pengamatan tanpa sepengetahuan subyek. Dalam artian subyek tidak mengetahui bahwa keberadaan peneliti sedang melakukan proses penelitian terhadap fenomena-fenomena yang ada, tindakantindakan dan kata-kata yang diutarakan subyek atau sumber lain pada peneliti. Tujuan tidak diketahuinya identitas peneliti, supaya proses pengamatan dan wawancara sebagai metode pengumpul data bisa dilakukan secara alami, tidak ditutup-tutupi, tidak dibuat-buat dan subyek terteliti bisa bebas mengutarakan apa yang dipikir dan dirasakan pada saat wawancara.

Penelitian fenomenologi mengamati subyek dalam kondisi yang alami, sehingga tidak ada batasan dalam memaknai atau memahami fenomena yang dikaji oleh peneliti, serta peneliti memiliki kebebasan dalam menganalisis data yang diperoleh. Untuk memperoleh data yang disesuaikan dengan fokus penelitian, subyek penelitian diambil menggunakan teknik pengambilan sampel secara snowball sampling (teknik bola salju) yakni salah satu teknik pengambilan sampel yang anggotanya tidak jelas keberadaannya dengan jumlah yang tidak pasti dengan cara menemukan satu sampel kemudian menanyakan keberadaan sampel lain secara berantai. Hal ini dilakukan untuk mendapatkan informasi dari subyek satu ke subyek lainnya secara berkelanjutan sehingga data yang diperoleh semakin lengkap dan komprehensif.

Dalam penelitian ini, peneliti awalnya mencari informasi dari subyek utama, kemudian menyebar ke subyek yang lain untuk melengkapi data yang diperlukan dalam penelitian. Informasi berkaitan dengan perilaku denial syndrome dengan indikasi perilaku masyarakat Pamekasan yang tidak peduli/ menolak terhadap protokol kesehatan dan adanya covid-19 sehingga dapat mengakibatkan penyebaran virus dengan cepat dan luas, perilaku masyarakat yang terlihat tutup mata terhadap dampak yang akan terjadi selama pandemi ini dan masih tetap beraktifitas normal serta tetap menyelenggarakan kegiatan-kegiatan yang seharusnya tidak dilakukan di kondisi pandemi seperti saat ini, serta bagaimana masyarakat Pamekasan menyikapi kondisi pandemi yang akhir-akhir ini semakin membludaknya orang sakit dan banyaknya kematian mendadak di lingkungan sekitar. Teknik analisis data dalam penelitian ini yakni mengubah transkrip rekaman wawancara menjadi tulisan, menginventarisasi pernyataan-pertanyaan dan hasil observasi yang relevan dengan topik, serta merinci pernyataan penting dari subjek untuk kemudian diformulasikan dalam suatu makna. 


\section{HASIL}

Denial Syndrome yang biasa disebut dengan perilaku Penyangkalan merupakan mekanisme pertahanan ego individu untuk menyesuaikan diri dengan situasi yang menyedihkan, menakutkan, dan situasi yang tidak sesuai dengan harapannya. Denial Syndrome untuk sementara waktu dapat mempertahankan kekuatan diri artinya dapat membuat individu nyaman secara psikologis sesuai dengan harapannya, tetapi akan berdampak lemahnya individu tersebut untuk menghadapi tantangan hidup apalagi untuk kondisi jangka panjang.

Pada Denial Syndrome individu akan berusaha untuk melindungi diri sendiri secara psikologi dengan menolak kenyataan, membantah kondisi-kondisi yang membuat individu tersebut tidak nyaman, serta tidak bisa menerima kebenaran akan kenyataan dalam menghadapi kondisi tertentu. Denial Syndrome untuk jangka pendek sementara diperlukan untuk membawa efek baik agar individu dapat menyesuaikan kondisi diri dengan hal yang menurutnya menyakitkan, karena Denial Syndrome merupakan cara individu dalam mengatasi konflik emosional, stress, pikiran yang menyakitkan, dan kecemasan. Pada saat individu mengalami Denial Syndrome maka individu tersebut belum bisa mengakui situasi yang sulit, tidak bisa menghadapi fakta dari masalah, mengecilkan konsekuensi/ dampak dari masalah tersebut.

Sementara Denial Syndrome akan membantu individu untuk berpikir logis, tetapi jika individu tersebut tetap dalam kondisi Denial Syndrome dalam jangka panjang dan individu tersebut tidak segera menerima kondisi yang terjadi dan menyelesaikan konflik psikologi (ketakutan, kecemasan, dll) dalam diri individu tersebut maka akan membahayakan dan menimbulkan masalah pada diri sendiri ataupun lingkungan sekitar. Salah satu bentuk Denial Syndrome yang tidak disadari dilakukan yakni perilaku-perilaku masyarakat yang menolak covid-19 dan menutup diri untuk memahami dampak dari covid-19.

Virus Corona atau severe acute respiratory syndrome coronavirus 2 (SARS-CoV2) adalah virus yang dapat menyerang sistem pernapasan. Penyakit karena infeksi virus ini disebut COVID-19. Virus Corona bisa menyebabkan gangguan ringan pada sistem pernapasan, infeksi paru-paru yang berat, hingga kematian. Virus ini bisa menyerang siapapun dengan rentang usia yang beragam, seperti lansia (golongan usia lanjut), orang dewasa, anak-anak, dan bayi, termasuk ibu hamil dan ibu menyusui. Jika dilihat dari persentase angka kematian berdasarkan rentang usia, maka kelompok rentang usia >60 tahun memiliki kemungkinan persentase angka kematian yang lebih tinggi dibandingkan golongan 
usia dibawahnya. Sedangkan jika dilihat berdasarkan jenis kelamin, pada umumnya 53,8\% penderita yang meninggal akibat COVID-19 adalah laki-laki dan 46,2\% sisanya berjenis kelamin perempuan (Pane, 2021)

Individu yang terpapar covid-19 memiliki gejala awal menyerupai gejala flu, yaitu demam diatas 38 derajat celcius, pilek, batuk kering, sakit tenggorokan, dan sakit kepala. Setelah itu, gejala yang ditimbulkan dapat hilang dan sembuh atau malah memberat. Penderita covid-19 dengan gejala yang berat dapat mengalami demam tinggi, batuk berdahak bahkan sampai mengeluarkan bercak darah, sesak nafas, dan nyeri dada. Gejala-gejala tersebut muncul ketika tubuh bereaksi melawan virus Corona. Secara umum, ada 3 gejala umum yang bisa menandakan seseorang terinfeksi virus Corona, yaitu: Demam (suhu tubuh melebihi 38 derajat Celsius), batuk kering, dan sesak nafas. Namun demikian juga terdapat gejala lain yang juga bisa terjadi pada individu meskipun lebih jarang, yakni diare, sakit kepala, konjungtivitis, hilangnya kemampuan mengecap rasa, hilangnya kemampuan untuk mencium bau (anosmia), serta ruam di kulit.

Gejala-gejala yang muncul ini pada umumnya terjadi dalam waktu 2 hari sampai 2 minggu setelah penderita terpapar virus Corona. Sebagian pasien yang terinfeksi virus Corona bisa mengalami penurunan pernafasan (oksigen) tanpa adanya gejala apapun. Kondisi ini disebut happy hypoxia, dan hal ini dapat menyebabkan kematian. Covid-19 ditetapkan sebagai pandemi global oleh organisasi kesehatan Dunia (WHO) (Dzulfaroh, 2021), yang memberikan dampak yang luar biasa pada berbagai negara di belahan dunia, dan tak luput Indonesia juga menjadi negara yang harus bangkit dari Pandemi Covid-19 ini. Indonesia berada di peringkat ke-14 Dunia kasus Covid-19 terbanyak, serta dalam 24 jam terakhir menjadi Negara dengan kasus kematian harian tertinggi di dunia yakni 1.566 kasus kematian (Dzulfaroh, 2021). Berbagai upaya pemerintah Indonesia dilakukan untuk mengurangi penyebaran Covid-19 mulai dari PSBB sampai PPKM Level 4. Pemberian vaksin tahap 1 dan tahap 2 kepada masyarakat merupakan salah satu upaya Pemerintah agar wabah corona ini segera berakhir.

Madura dalam 2 bulan terakhir (Juni 2021- Juli 2021) menjadi bahan perbincangan karena melonjaknya kasus covid-19. Periode bulan Juni 2021 terjadi lonjakan tajam kasus covid-19 terbaru yakni varian Delta terjadi pulau Madura, terutama di Kabupaten bangkalan dan ketiga kabupaten lainnya. Bahkan menurut pakar kesehatan peningkatan kasus di pulau Madura bisa jauh lebih besar dari kasus yang tercatat (Mustopa, 2021). Lonjakan kasus covid-19 erat kaitannya dengan perilaku masyarakat dalam mematuhi protokol kesehatan 
selama terjadinya pandemi. Berdasarkan hasil penelitian tentang fenomena perilaku warga Pamekasan untuk menyikapi pandemi ini yakni masih kurang pedulinya masyarakat dengan protokol kesehatan yang dianjurkan oleh pemerintah.

PPKM yang digalakkan oleh pemerintah daerah untuk menekan lajunya kasus masyarakat yang terinfeksi covid-19 bisa dikategorikan tidak sesuai dengan harapan. Pasar tradisional masih tetap ramai tanpa adanya jaga jarak dan masyarakat juga terlihat banyak yang tidak menggunakan masker. Bahkan menurut penuturan Hosriyah yang berprofesi sebagai penjual nasi dan setiap hari ke pasar Blumbungan, jika memakai masker akan terlihat aneh karena hampir sebagian besar penjual dan pembeli di pasar bebas beraktivitas tanpa memperhatikan protokol kesehatan. Bahkan saat ia dan seluruh anggota keluarganya sakit (menunjukkan gejala covid-19), ia masih dijeguk oleh teman dan tetangganya dengan dalih corona itu tidak ada dan penyakit seperti ini adalah tha'un. Adapun Protokol kesehatan biasanya hanya dilaksanakan di instansi-instansi pemerintah dan swasta (misalnya bank dan swalayan), serta apotek. Tetapi untuk tempat-tempat umum, masih sulit untuk meningkatkan kesadaran warga untuk melaksanakan protokol kesehatan covid-19.

Tak jauh berbeda dengan yang diungkapkan oleh Ani seorang ibu rumah tangga di desa Samiran, dimana saat ia merasakan kondisi tubuhnya berbeda yakni merasakan mulai kehilangan indra penciuman dan perasa serta tubuhnya menggigil, ia tetap beraktifitas seperti biasanya bahkan berkomunikasi layaknya orang sehat dengan warga sekitar. Hal ini ia lakukan dengan asumsi agar ia tetap sehat, dan anggapannya ia sakit biasa walaupun sebenarnya ciri-ciri tersebut mengarah ke covid-19 (gejala panas menggigil, lemas, badan terasa sakit dan ngilu, serta kehilangan indra perasa dan penciuman). Anggapan bahwa covid19 itu menakutkan dan akhirnya masyarakat menyebutnya dengan kata "Penyaket satiyaan" adalah cara untuk mereka tidak takut bersinggungan dengan pasien yang sakit. Sehingga warga yang sakit masih tetap dikunjungi dan masih bisa berinteraksi dengan warga lainnya termasuk Ani.

Jumlah pasien yang membeludak di berbagai rumah sakit baik RSUD maupun rumah sakit swasta, mengindikasikan bahwa pandemi ini belum berakhir namun bagi masyarakat yang menolak percaya adanya covid seolah menjadi hal yang lumrah terjadi dan tidak menakutkan. Banyaknya berita kematian di berbagai desa, seolah-olah bukan disebabkan karena mewabahnya covid-19, bahkan informasi yang dirangkum oleh CNN Indoensia.Com bahwa warga yang meninggal di salah satu desa di kabupaten Pamekasan mencapai 50 orang dalam 2 pekan dan dari beberapa dari yang meninggal menunjukkan gejala sesak nafas, 
sehingga ketua DPRD Pamekasan melarang pengurus masjid untuk mengumumkan warga yang meninggal dunia melalui pengeras suara (Nurus, 2021). Tak jauh berbeda dengan desa Bindang pasean, angka kematian dalam kurun waktu 2 bulan terakhir (juni dan Juli) meningkat drastis dibandingkan bulan-bulan sebelumnya.

Dari hasil pengamatan di desa blumbungan, dalam kurun 2 bulan berita kematian cukup sering, yakni belum 7 hari salah satu warga meninggal kemudian terdapat berita kematian warga yang lain, bahkan dalam 1 dusun bisa sampai 3 orang meninggal dalam kurun waktu bersamaan. Tidak jauh berbeda dengan yang terjadi di kelurahan kanginan, juga banyak orang yang meninggal dengan menunjukkan gejala sesak nafas (mengarah ke covid19), padahal tidak memiliki riwayat penyakit asma/ pernafasan lainnya.

Sesuai dengan budaya di madura khususnya pamekasan, jika ada orang yang meninggal maka akan menyelenggarakan tahlil (doa bersama) dan warga yang lain akan melayat ke rumah duka. Seorang ibu rumah tangga di Desa Blumbungan meninggal dunia dan dinyatakan positif covid-19, keluarga besarnya tetap menerima tamu untuk berbela sungkawa, bahkan dari hasil pengamatan warga yang melayat cukup banyak dan berkerumun serta banyak yang tidak menggunakan masker. Ibu korban yang meninggal menyebutnya "penyaket satiyaan" (penyakit terkini/ Covid-19), walaupun berita penyebab meninggalnya karena covid-19 orang yang melayat dan tahlil tetap jumlahnya banyak, bahkan untuk orang yang tahlil setiap malam bisa lebih dari 100 orang tanpa menggunakan masker dan protokol kesehatan lainnya. Namun, tidak semua warga yang meninggal dengan indikasi covid-19 menerima tamu dan menyelenggarakan doa bersama, untuk warga yang tinggal di daerah kota biasanya lebih memilih menerima bahwa covid-19 berbahaya sehingga tidak menerima tamu dan memilih untuk keluarga yang meninggal di doakan oleh keluarga terdekat sendiri. Tetapi untuk yang tinggal di pinggiran dan di desa, maka hal ini tidak berlaku. Penuturan Muslimah seorang ibu rumah tangga juga menuturkan bahwa dalam 1 hari beliau bisa melayat orang meninggal lebih dari 2 tempat, karena banyaknya warga yang meninggal dalam kurun waktu yang sama.

Setelah Idul Adha, masyarakat Madura khususnya Pamekasan meyakini bahwa bulan baik untuk melangsungkan pernikahan. Walaupun kondisi pandemi, tetapi banyak keluarga yang tetap menyelenggarakan pernikahan tanpa memperhatikan protokol kesehatan, terlebih di daerah pinggiran kota dan desa-desa di kabupaten Pamekasan. Bahkan dari hasil pengamatan, salah satu keluarga yang menyelenggarakan pernikahan dalam kondisi sakit dengan menunjukkan gejala covid-19, yakni batuk, panas, sesak nafas, dan ciri lainnya. tetapi 
hal tersebut tidak menyurutkan keinginan untuk tetap menyelenggarakan pernikan dengan menghadirkan tamu undangan, bahkan lebih dari 150 orang.

Hasil riset melalui observasi dan wawancara mengenai perilaku-perilaku masyarakat Pamekasan dalam menghadapi pandemi Covid-19 menunjukkan Denial Syndrome yang berkepanjangan salah satunya adalah perilaku tidak mentaati protokol kesehatan, sehingga dampak yang ditimbulkan adalah menyebarnya virus dengan cepat dan luas yang mengakibatkan jumlah kasus terinfeksi positif Covid-19 dan yang meninggal semakin meningkat.

\section{PEMBAHASAN}

Menurut Freud setiap individu memiliki mekanisme pertahanan diri atau disebut defence mechanisms, hal ini terjadi dikarenakan adanya dorongan perasaan untuk mencari pengganti objek. Upaya pertahanan diri yang dilakukan untuk melindungi diri dari perasaan yang dapat menimbulkan rasa sakit kepada individu. Menurut Freud, mekanisme pertahanan ego sebagai cara untuk menekan dorongan id dan superego atas ego yang dapat menimbulkan kecemasan karena kondisi yang dialami individu dapat dikurangi ataupun diredakan (Kuntojo, 2015). Freud menyatakan bahwa mekanisme pertahanan ego itu adalah mekanisme yang rumit dan banyak macamnya salah satunya adalah perilaku Denial (penyangkalan). Mekanisme pertahanan diri Denial Syndrome merupakan jenis pertahanan yang sering digunakan oleh individu (Bellak dan Abrams, 1997). Denial dapat terjadi dengan menyangkal kenyataan atau menyangkal impuls-impuls. Penyangkalan akan kenyataan biasa terlihat dimana orang berusaha untuk menghindari ancaman yang dikenal (Pervin dan John, 1997).

Adapun ciri-ciri jika individu sedang melakukan penyangkalan sebagai mekanisme pertahanan diri terhadap kondisi yang sedang dihadapi yakni; (1) individu tersebut terkesan menolak untuk membicarakan masalah yang sedang dihadapi/ yang ditakutkan (2) individu tersebut memiliki alasan untuk membenarkan perilaku diri sendiri walaupun tidak sesuai dengan aturan atau melanggar aturan (3) akan menyalahkan pihak lain atau siapapun karena munculnya masalah tersebut (4) memilih untuk bertahan dalam suatu perilaku meskipun dampak dari perilaku tersebut negatif/ membahayakan (5) menghindari memikirkan masalah yang sedang dihadapi (Mardatila, 2021).

Pada masyarakat Pamekasan Denial Syndrome terhadap kondisi pandemi covid-19, pada awalnya dilakukan untuk mengurangi kecemasan dan ketakutan karena informasi- 
informasi tentang covid-19 di media massa dan media sosial. Dalam kondisi tersebut, individu memilih untuk menyangkal tentang bahaya Covid-19 dengan berbagai alasan meskipun sudah ada bukti atau data faktual yang ditunjukkan oleh ahlinya yakni dampak Covid-19 bisa menyebabkan gangguan pada sistem pernapasan, pneumonia akut, sampai kematian (Nisa, 2021). Selain dampak covid-19 yang menyebabkan kecemasan pada masyarakat, sakit atau kematian karena dinyatakan positif covid-19 juga menjadi hal yang ditakutkan karena khawatir akan dijauhi oleh warga yang lain. Hal tersebut dapat menjadi penyebab munculnya perilaku Denial Syndrome pada masyarakat kabupaten Pamekasan. Sesuai dengan arahan pemerintah, bahwa pasien positif covid-19 dianjurkan isolasi mandiri (Isoman), dan jika berada di rumah sakit akan di rawat di ruang isolasi, serta jika meninggal dengan positif covid-19 akan dilaksanakan pemakaman dengan menggunakan protokol covid-19. Hal-hal tersebut menjadi ketakutan karena bertentangan dengan tradisi yang biasanya dilakukan oleh masyarakat Pamekasan. Misalnya jika sedang dalam kondisi sakit, maka sudah menjadi tradisi untuk di jenguk, dan jika ada warga yang meninggal maka tradisi membantu menyiapkan makanan, menguburkan, dan melaksanakan doa bersama (tahlil) menjadi kegiatan yang harus dilakukan oleh warga lainnya. Ketakutan akan sendirian dan tidak dihiraukan oleh sekitar menjadi hal yang sangat menakutkan dibandingkan dampak dari pandemi tersebut.

Selain penerapan isolasi mandiri terhadap pasien positif covid-19 dan pemakaman dengan protokol covid-19, berbagai upaya pencegahan telah dilakukan untuk mengurangi penyebaran covid-19 diantaranya karantina wilayah, kebijakan, social distancing, mematuhi protokol kesehatan dengan memakai masker, jaga jarak, vaksinasi dan lain sebagainya. Kebijakan-kebijakan tersebut dapat menghambat kegiatan masyarakat, misalnya pedagang di pasar, tukang bangunan, penjual kaki lima, dan jenis pekerjaan lainnya. Untuk menolak kebijakan-kebijakan yang tidak sesuai dengan harapan tanpa memikirkan dampak dari perilaku terhadap diri sendiri dan orang lain, penolakan/ penyangkalan terhadap kondisi ini bisa menjadi salah satu alternatif agar kondisi mental tetap sehat untuk sementara waktu dan dapat mengakibatkan dampak negatif jika individu tersebut masih menunjukkan perilaku Denial Syndrome dalam waktu yang lama. Adapun dampaknya antara lain melonjaknya warga yang positif covid-19 dengan jumlah total 1.406 orang positif Covid-19 dan jumlah warga yang meninggal sebanyak 122 orang per tanggal 06 Juli 2021 (Tanjung, 2021).

Perilaku tidak menggunakan masker saat beraktivitas ataupun saat berada di tempat umum, mengumpulkan massa atau menimbulkan kerumunan, tidak melakukan isolasi 
mandiri warga yang menunjukkan gejala covid-19, menolak dinyatakan positif covid-19 bagi pasien yang sakit ataupun meninggal, tetap melaksanakan perayaan pernikahan di tengahtengah wabah covid, serta mengganti istilah covid-19 dengan Penyaket Satiyaan atau Tha'un. Perilaku-perilaku tersebut jika dikorelasikan dengan ciri-ciri perilaku Denial syndrome maka dapat disimpulkan bahwa fenomena tersebut merupakan perilaku penyangkalan (Denial syndrome) masyarakat Pamekasan terhadap pandemi covid-19.

Denial syndrome dapat membuat emosi individu terkendali/kenyamanan psikologisnya, namun lambat laun individu tersebut harus beradaptasi terhadap kondisi yang dirasa menakutkan dan tidak sesuai dengan harapan sehingga pada akhirnya dapat menemukan solusi dan mengambil sikap yang harus dilakukan. Termasuk di masa pandemi, menerima dan menyadari dampak covid-19 bagi diri dan orang lain di lingkungan sekitar dengan melakukan berbagai usaha agar tetap dapat menjalankan rutinitas tanpa bertentangan dengan aturan pemerintah, akan menjadi solusi untuk individu keluar dari zona nyaman dan berdamai dengan diri sendiri dan keadaan. Perilaku denial yang ditunjukan oleh masyarakat Madura dipengaruhi oleh budaya yang ada di pulau tersebut. Masyarakat madura memiliki harga diri yang kuat. Harga ini pada satu sisi memberikan dampak positif karena meningkatkan resiliensi terutama pada remaja dan orang dewasa (Rahmasari et al., 2014). Pada sisi lain, harga diri yang tinggi dapat menyebabkan seseorang melakukan perilaku denial.

Dampak dari perilaku denial yang dilakukan oleh masyarakat Madura selain menyebabkan semakin cepatnya penularan virus Covid-19 di wilayah ini juga akan berdampak pada kondisi psikologis masyarakat. Perilaku denial pada masa yang akan datang akan menimbulkan kecemasan dan masalah hubungan interpersonal dengan orang lain (Vos \& De Haes, 2007). Perilaku denial yang ditunjukan oleh masyarakat bisa jadi menyebabkan perselisihan jika tidak diatasi. Untuk menghadapi situasi ini dibutuhkan keterampilan komunikasi interpersonal yang baik terutama oleh tokoh masyarakat agar dapat menyadarkan masyarakat tentang pentingnya melakukan protokol kesehatan selama pandemi. Hal ini senada dengan penelitian yang telah membuktikan bahwa masyarakat Madura mengacu pada sistem hierarki sosial (Hefni, 2012).

Penelitian telah membuktikan bahwa perilaku denial dapat disanggah dengan melakukan komunikasi interpersonal yang baik. Salah satu tujuan dari komunikasi interpersonal adalah untuk mempengaruhi orang lain (Dewanti \& Novitasari, 2020). Strategi 
komunikasi interpersonal telah terbukti dapat mengurangi perilaku denial masyarakat (Häkkinen \& Akrami, 2014).

\section{SIMPULAN}

Selama masa pandemi Covid-19 masyarakat di Pamekasan Madura menunjukan perilaku denial syndrome. Mereka cenderung tidak mempercayai dampak dari Covid-19. Perilaku denial yang ditunjukan oleh masyarakat madura selama menghadapi Covid-19 antara lain tetap melaksanakan tahlilan bagi jenazah yang meninggal karena Covid-19, menyelenggarakan pesta pernikahan dan kegiatan lain yang melibatkan orang banyak (tidak mentaati protokol kesehatan).

Masyarakat Kabupaten Pamekasan harus keluar dari kondisi Denial Syndrome dengan menerima dan menyadari dampak virus corona bagi diri sendiri dan orang lain, melakukan berbagai usaha untuk tetap dapat menjalankan rutinitas tanpa bertentangan dengan aturan pemerintah sehingga akan menjadi solusi untuk individu keluar dari zona nyaman dan berdamai dengan diri sendiri dan keadaan.

Meskipun penelitian ini telah berhasil memaparkan perilaku denial masyarakat Madura, namun penelitian ini memiliki keterbatasan yaitu dilakukan pada kelompok masyarakat tertentu. Saran untuk penelitian selanjutnya sebaiknya menggunakan sampel penelitian yang lebih besar dengan memperhatikan karakteristik perilaku denial pada setiap kelompok masyarakat misalnya laki-laki dan perempuan dan kelompok usia tertentu.

\section{DAFTAR RUJUKAN}

Aziz, A. (2021, Juni 25). Cegah meluasnya COVID-19, keluar masuk Pamekasan wajib punya SIKM. Retrieved Juli 28, 2021, from Antara News: https://www.antaranews.com/berita/2232126/cegah-meluasnya-covid-19-keluarmasuk-pamekasan-wajib-punya-sikm

Bellak, 1. d. (1997). The T.A.T., The C.A.T., and The S.A.T. . Boston: Bacon.

Corey, G. (2005). Teori dan Praktek Konseling dan Psikoterapi. bandung: Refika Aditama .

Creswel, 1. (1998). Qualitative Inquiry and Research Design: Choosing among Five Tradition. London: Sage Publications.

CSSEGISandData /Covid-19. (2021, Juli 26). Retrieved Juli 27, 2021, from CSSEGISandData /Covid-19: https://github.com/CSSEGISandData/COVID-19

Dea. (2020, Juni 13). Tolak Protokol, Warga Pamekasan Ambil Paksa Jenazah Covid-19. Retrieved Juli 30, 2021, from CNN Indonesia: https://www.cnnindonesia.com/nasional/20200613204223-20-513048/tolak-protokolwarga-pamekasan-ambil-paksa-jenazah-covid-19

Dewanti, S. R., \& Novitasari, Z. (2020). Examining Guidance and Counseling Students Interpersonal Communication Skill based on Semester Level. Psychology, Evaluation, and Technology in Educational Research, 2(2), 129-136. 
Dzulfaroh, A. N. (2021, $\quad$ Maret 11$)$. https://www.kompas.com/tren/read/2021/03/11/104000165/hari-ini-dalam-sejarah-who-tetapkan-covid-19-sebagai-pandemi-global?page=all. Retrieved Juli 29, 2021, from KOMPAS.Com: https://www.kompas.com/tren/read/2021/03/11/104000165/hari-ini-dalam-sejarah-who-tetapkan-covid-19-sebagai-pandemi-global?page=all

Dzulfaroh, A. N. (2021, Juli 24). UPDATE Corona 24 Juli: Indonesia Catat Angka Kematian Harian Tertinggi, Peringkat 14 Kasus Terbanyak di Dunia. Retrieved Juli 29, 2021, from KOMPAS.com: https://www.kompas.com/tren/read/2021/07/24/082000465/update-corona-24-juliindonesia-catat-angka-kematian-harian-tertinggi?page $=$ all

Fea. (2021, Juni 23). Pasien Covid-19 Melonjak, RSUD Pamekasan Buka Tenda Darurat. Retrieved Juli 28, 2021, from CNN Indonesia: https://www.cnnindonesia.com/nasional/20210703041604-20-662599/pasien-covid19-melonjak-rsud-pamekasan-buka-tenda-darurat

Häkkinen, K., \& Akrami, N. (2014). Ideology and Climate Change Denial. Personality and Individual Differences, 70, 62-65.

Hefni, M. H. M. (2012). BHUPPA'-BHÂBHU'-GHURU-RATO (Studi KonstruktivismeStrukturalis tentang Hierarkhi Kepatuhan dalam Budaya Masyarakat Madura). Karsa: Journal of Social and Islamic Culture, 11(1), 12-20.

Kabupaten Pamekasan. (2021). Retrieved Juli 27, 2021, from jatim.bpk.go.id: https://jatim.bpk.go.id/kabupaten-pamekasan/

Kuntojo. (2015). Psikologi perkembangan. Jogjakarta: Diction.

Kuswarno, E. (2009). Metedologi Penelitian Komunikasi Fenomenologi; Konsepsi, Pedoman, dan Contoh Penelitian. Bandung: Widya Padjajaran.

Mardatila, A. (2021, Juni 22). Mengenal Denial Syndrome, Kenali Tanda-tanda Beserta Dampak Jangka Panjangnya. Retrieved Juli 30, 2021, from Merdeka.com: https://www.merdeka.com/sumut/mengenal-denial-syndrome-kenali-tanda-tandabeserta-dampak-jangka-panjangnya-kln.html

Mustopa. (2021, Juni 27). Covid di Indonesia: Lonjakan kasus terjadi di Madura, epidemiolog duga jumlah sebenarnya bisa jauh lebih besar. Retrieved Juli 28, 2021, from BBC News Indonesia: https://www.bbc.com/indonesia/indonesia-57367994

Nisa, I. S. (2021, Maret 31). Dampak Covid-19 dalam Bidang Kesehatan . Retrieved Juli 30, 2021, from unair.ac.id: http://ners.unair.ac.id/site/index.php/news-fkp-unair/30lihat/1181-dampak-covid-19-dalam-bidang-kesehatan

Nurus. (2021, juli 23). Pengurus Masjid di Pamekasan Dilarang Umumkan Orang Meninggal. Retrieved Juli 29, 2021, from CNNIndonesia: https://www.cnnindonesia.com/nasional/20210723131502-20-671264/pengurusmasjid-di-pamekasan-dilarang-umumkan-orang-meninggal

Pane, d. M. (2021, Juli 23). Virus Corona. Retrieved Juli 28, 2021, from ALODOKTER: https://www.alodokter.com/virus-corona

Pervin, L. A. (1997). Theory And Research, 7th edition. Inc: John Wiley \& Sons.

Rahmasari, D., Jannah, M., \& Puspitadewi, N. W. S. (2014). Harga Diri dan Religiusitas dengan Resiliensi pada Remaja Madura Berdasarkan Konteks Sosial Budaya Madura. Jurnal Psikologi Teori Dan Terapan, 4(2), 130-139.

Rizal, J. G. (2021, Juli 26). Daftar 10 Provinsi di Indonesia dengan Kematian Tertinggi akibat Covid-19. Retrieved Juli 27, 2021, from Kompas.Com: https://www.kompas.com/tren/read/2021/07/26/092900565/daftar-10-provinsi-diindonesia-dengan-kematian-tertinggi-akibat-covid-19?page=all 
Tanjung, E. (2021, Juli 06). Melonjak, Kasus Covid-19 di Pamekasan Madura Bertambah 13 Pasien. Retrieved Juli 30, 2021, from Suarajatim.id: https://jatim.suara.com/read/2021/07/06/174318/melonjak-kasus-covid-19-dipamekasan-madura-bertambah-13-pasien

Vos, M. S., \& De Haes, J. (2007). Denial in cancer patients, an explorative review. Psycho-Oncology: Journal of the Psychological, Social and Behavioral Dimensions of Cancer, 16(1), 12-25. 